\title{
The Relationship between of Rural Accessibility and Development
}

\author{
Thomas Soseco \\ Faculty of Economics, Universitas Negeri Malang, Indonesia \\ Email: thomassoseco@gmail.com
}

Received: April 21, 2016; Accepted: August 26, 2016; Published: November 4, 2016

Permalink/DOI: http://dx.doi.org/10.17977/um002v8i22016p131

\begin{abstract}
Rural accessibility has been an important issue for development. As wider accessibility allow people to increase their living standard, there is an urgency to compose a single indicator to measure accessibility. The World Bank has been produced Rural Access Index (RAI). That index measure the percentage of rural population living within two kilometers from all-season road. Even though this index is useful to compare among countries, there are obstacles experienced especially in developing countries like Indonesia. The first barrier is data availability. Then, the second barrier is the unequal population distribution in Indonesia. However, the index is still needed to solve many problems in Indonesia, e.g. health and lack of infrastructure.
\end{abstract}

Keywords: Rural Access Index (RAI), accessibility, rural area JEL Classification: O18, R11, R12

\section{INTRODUCTION}

Adequate access to transport goods and people allow community to enhance their living standard. This is caused by their ability to select many commodities to consume and also expand their economic activities. Through adequate access, both in urban and rural areas, people can significantly reduce their traveling time and transporting cost.

The essential of adequate access has been examined by many scholars. Soseco (2015); Soseco (2016) observed the importance of education sector in rural areas in Indonesia. His findings found that educational progress can only be achieved by better accessibility. Fan \& Kang (2005) examined the factors which contributed to the exceptional growth and to the reduction of poverty in China during the past thirty years. They concluded that whilst the rapid introduction of the expressway network did play a part, the much shorter lengths of low standard feeder roads made an even more important contribution to growth and poverty reduction, achieving about four times greater benefit/cost ratio than did the expressways. Similarly, Gannon \& Liu (1997) contend that improved transport contributed not only through enabling better access to services and opportunities but also by lowering the transport costs incurred in delivering and/or accessing such services and opportunities.

Indonesia as a big country cope with its huge land area. This creates the challenge to provide a satisfactory road conditions. The urgency of better access should be tracked through observing its relationship with economic development. 
This article will provide initial approach the importance of satisfactory access in rural areas in Indonesia and problems related to economic development.

\section{ACCESSIBILITY IN RURAL AREAS}

Rural access plays enormous role in society. First of all, poor access will create physical isolation (Roberts et al., 2006). Physical isolation is the strong contributor to poverty. Similar argument stated by Bird et al. (2007). Ashley and Maxwell (2001) also stated that poverty is not only widespread in rural areas but most poverty us rural. Second, poor access creates poor equity and unequal distribution of development. It caused by the high cost and longer time needed to reach certain areas may lagged goods and people delivery. Similar argument stated by Roberts \& KC (2005) who explained that the lack of reliable transport system in poor countries drive households to spend significant time traveling in order to meet basic needs. Moreover, Irigoyen (2007) described aspects influenced by an improved rural access as seen in figure 1.

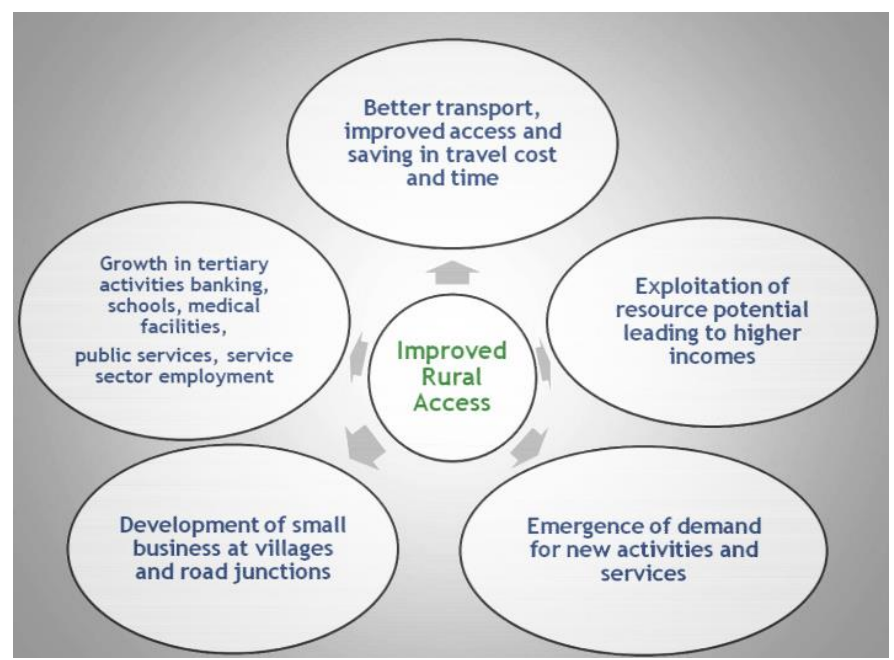

Figure 1. Aspect Influenced by Improved Rural Access Source: Irigoyen (2007)

Improved rural access drive to better transport, improved access and saving in travel cost and time. Then, this can leads to higher exploitation to potential resources that leading to higher incomes. Improved rural access also make the emergence of demand of new activities and services. Besides, it also improve the development of small businesses at villages. Also, this will stimulates growth in tertiary activities like banking, schools, medical services, public services.

Accessibility in one country can be measured by indicator developed by The World Bank. The Rural Access Index (RAI) is measured from analysis of surveys that include questionnaire about access to transport. The questionnaire also includes household's characteristics, time and distance from education provider, health facility, and water supply. The index ranged from 0 to 100, with 0 means worst access and 100 is the full-access. Figure 2 shows the worldwide distribution of rural access index. 


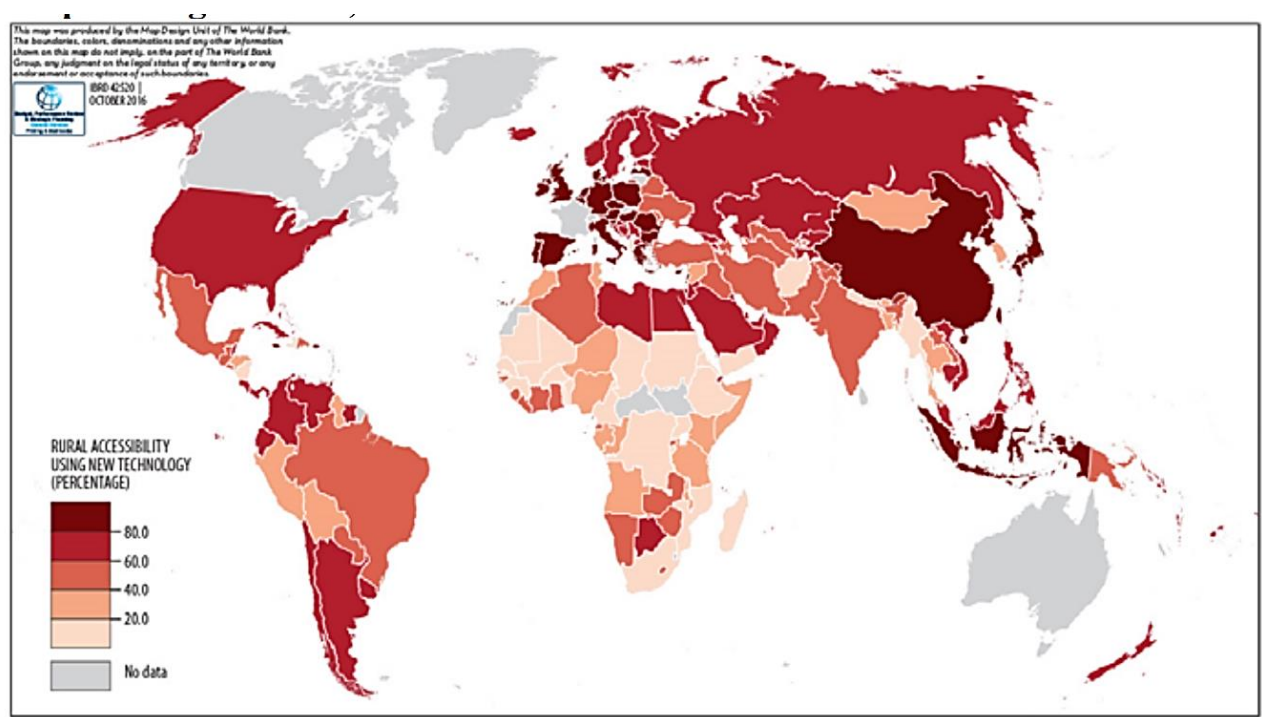

Figure 2. Rural Access Index

Source: Iimi et al., 2006

From 66 countries, grouped in six regions, the lowest RAI was in SubSaharan Africa (Figure 3). There were 24 countries surveyed and the average RAI value was $30 \%$. This means that only $30 \%$ of rural population have adequate access to facilities. The rest had no access. This is far from East Asia countries, where 94\% of rural population had normal access.

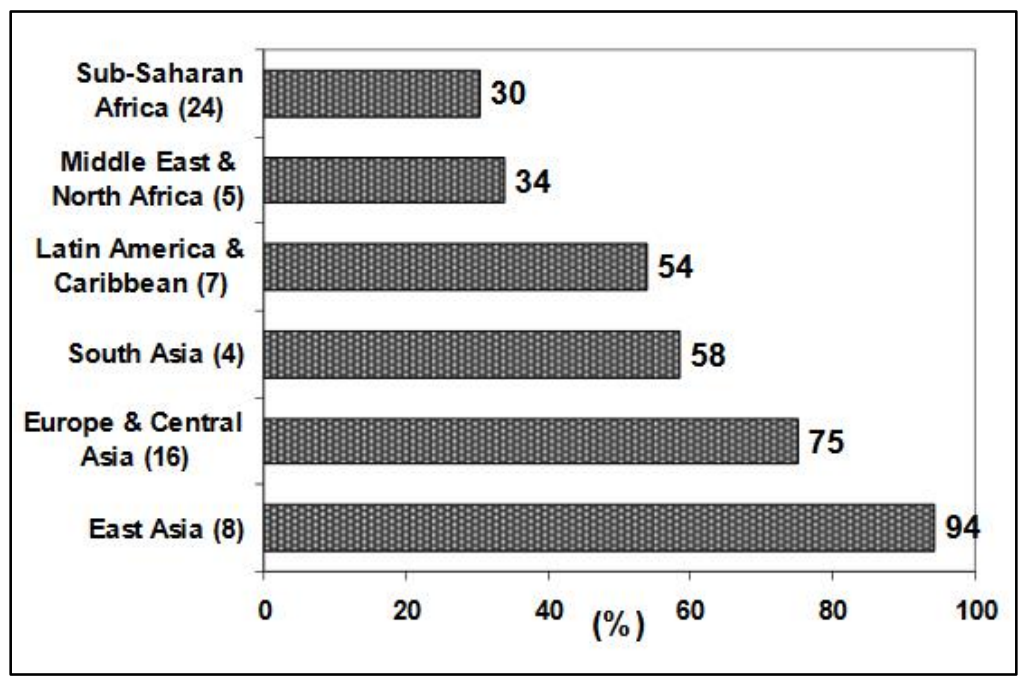

Figure 3. Rural Access: Regional Estimates (Number of Countries Included).

Source: Worldbank (2006)

Specifically, Roberts et al. (2006) defined The Rural Access Index (RAI) as measurement of the number of rural people who live within two kilometers (typically equivalent to a walk of 20-25 minutes) of an all-season road as a proportion of the total rural population. An "all-season road" is a road that is motorable all year round by the prevailing means of rural transport (typically a pikup or a truck which does not have four-wheel-drive). Occasional interruptions of short duration during inclement weather (e.g. heavy rainfall) are accepted, particularly in lightly trafficked roads. 
Roberts et al. (2006) also mentioned that some sections of the population (the elderly, the disabled or those carrying heavy burdens) may find that even distances of less than one kilometer present a significant barrier to access, particularly under extreme conditions of terrain or climate. On the other hand, on many remote situations, people may be accustomed to walking many kilometers in order to reach formal transport services. Alternatively, they may manage without using such transport at all. The choice of two kilometers as the defining distance for 'adequate access' is a compromise between these extremes. This establishes a consistent definition of the index, enabling comparison and aggregation (on the basis of population weight) of the values for target populations.

Due to lack of sufficient data, World Bank (2006) used two measurements to count RAI. The first, network models. Accessibility is affected by length of road network, habitable land area, distribution of roads, and distribution of population. This model can be showed as below:

Access $=\mathrm{f}[($ length of road network $) *($ habitable land area $) *($ distribution of roads) * (distribution of population)]

This model employs two kinds of data that widely available: the road length and the arable land area.

The second measurement is Quick Accessibility Mapping. Roberts et al. (2006) mentioned that this is a simplified version of a full GIS-based measure. The "quick map" is prepared by overlaying the roadmap on the topographical country map. The RAI is determined on the basis of an informed approximation for the population distribution of the country in question.

Various studies indicated that there is a usefulness of using RAI in make further development. For example, World Bank (2006) that found high Rural Access Index (RAI) also have low maternal mortality rates, as seen in table 1.

Table 1. Relationship between Maternal Mortality Rate and Rural Access Index

\begin{tabular}{lllllllc}
\hline No. & Country & $\begin{array}{c}\text { Maternal } \\
\text { Mortality } \\
\text { Rate }\end{array}$ & $\begin{array}{c}\text { Rural } \\
\text { Access } \\
\text { Index }\end{array}$ & No. & Country & $\begin{array}{c}\text { Maternal } \\
\text { Mortality } \\
\text { Rate }\end{array}$ & $\begin{array}{c}\text { Rural } \\
\text { Access } \\
\text { Index }\end{array}$ \\
\hline 1. & Sierra Leone & 2,000 & 65 & 11. & Portugal & 5 & 88 \\
2. & Malawi & 1,800 & 38 & 12. & Italy & 5 & 98 \\
3. & Angola & 1,700 & 42 & 13. & Ireland & 5 & 93 \\
4. & Niger & 1,600 & 37 & 14. & Denmark & 5 & 99 \\
5. & Tanzania & 1,500 & 38 & 15. & Kuwait & 5 & 82 \\
6. & Rwanda & 1,400 & 52 & 16. & Spain & 4 & 95 \\
7. & Mali & 1,200 & 14 & 17. & Austria & 4 & 95 \\
8. & Chad & 1,100 & 5 & 18. & Sweden & 2 & 86 \\
9. & Guinea-Bissau & 1,100 & 52 & 19. & Malta & 0 & 100 \\
10. & Somalia & 1,100 & 40 & 20. & Iceland & 0 & 81 \\
\hline
\end{tabular}

Source: World Bank, 2006

In Vietnam, improved rural access significantly reduce poverty in period of 1999 to 2004. Irigoyen (2007) found that, in India, there was an evidence that connected villages (provided by public roads) had higher annual average income (and annual average expenditure) comparing to unconnected villages. Also, connected villages had higher changes in maternal deaths and changes mortality under 5 years age. In India, public road could motivate higher females enrollment 
rate in schools. Next, Iimi et al. (2016) found RAI, specifically road expansion is the major contributor for poverty alleviation.

Lastly, World Bank (2016a) found that there is a positive correlation between Rural Access Index and Gross Domestic Product Per Capita (Figure 4). Higher RAI (means better access) will create higher welfare.

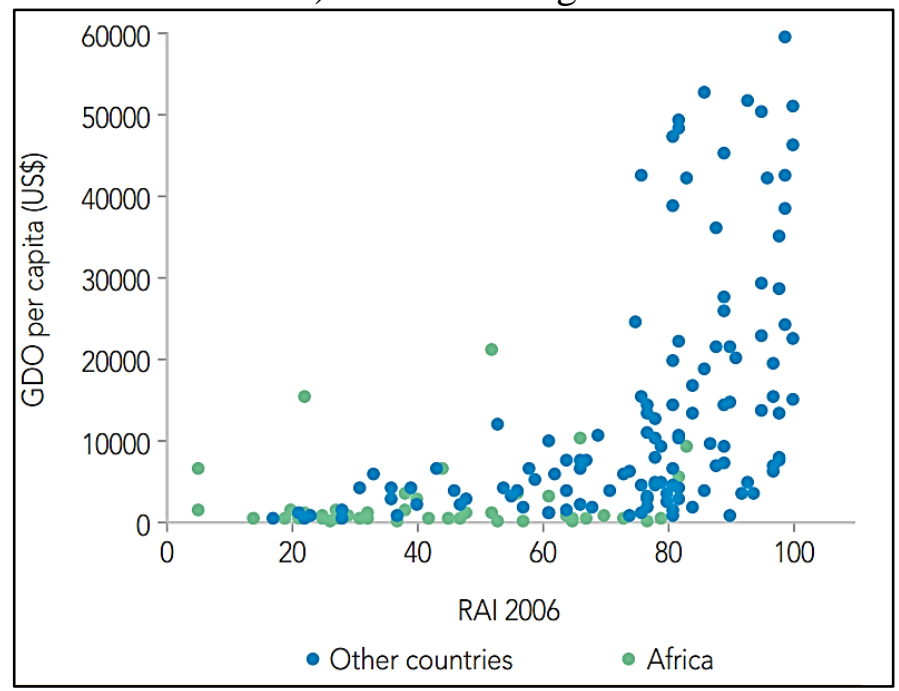

Figure 4. Gross Domestic Product Per Capita and Rural Access Index Source: World Bank (2016a)

\section{RURAL ACCESS IN INDONESIA}

World Bank (2016b) found that Indonesian Rural Access Index (RAI) in 2004 was $94 \%$. It means that there were 94 percent of rural population who are with adequate access (within 2 kilometres from all-season roads) and 6 percent of rural population were lack of adequate access. Table 2 shows the RAI for ASEAN countries.

Table 2. RAI for ASEAN Countries

\begin{tabular}{lcccccc}
\hline \multicolumn{1}{c}{ Country } & Year & $\begin{array}{c}\text { Rural } \\
\text { Access } \\
\text { Index }\end{array}$ & $\begin{array}{c}\text { Total } \\
\text { Population } \\
(2004)\end{array}$ & $\begin{array}{c}\text { Rural } \\
\text { Population } \\
(2004)\end{array}$ & $\begin{array}{c}\text { Rural } \\
\text { Population } \\
\text { with } \\
\text { Access }\end{array}$ & $\begin{array}{c}\text { Rural } \\
\text { Population } \\
\text { without } \\
\text { Access }\end{array}$ \\
\hline Brunei & 1999 & $81 \%$ & 365,687 & 98,662 & 80,257 & 18,406 \\
Darussalam & & & & & & \\
Cambodia & 2003 & $81 \%$ & $13,798,123$ & $11,157,162$ & $9,003,830$ & $2,153,332$ \\
Indonesia & 2003 & $94 \%$ & $217,587,504$ & $115,582,480$ & $108,647,531$ & $6,934,949$ \\
Lao PDR & 2002 & $64 \%$ & $5,791,695$ & $4,618,298$ & $2,974,184$ & $1,644,114$ \\
Malaysia & 2001 & $82 \%$ & $24,894,488$ & $8,414,337$ & $6,884,369$ & $1,529,968$ \\
Myanmar & 1999 & $23 \%$ & $50,003,988$ & $34,962,788$ & $8,144,903$ & $26,817,885$ \\
Philippines & 2003 & $80 \%$ & $81,617,024$ & $31,128,732$ & $24,902,986$ & $6,225,746$ \\
Singapore & n.a. & n.a. & $4,240,300$ & & 0 & \\
Thailand & 2000 & $33 \%$ & $63,693,660$ & $43,273,472$ & $14,137,664$ & $29,135,808$ \\
Timor-Leste & 2001 & $90 \%$ & 924,642 & 683,310 & 611,563 & 71,748 \\
Vietnam & 2004 & $84 \%$ & $82,162,088$ & $60,816,376$ & $50,781,674$ & $10,034,702$ \\
\hline
\end{tabular}

Source: Roberts, et al. (2006)

Several obstacles are exist in measuring RAI in Indonesia. First of all, the data availability. Because RAI requires information regarding length of road 
network, habitable land area, distribution of roads, and distribution of population, the information available will be hardly found. Data available are only length of roads and their status/condition. This is because roads are mainly built and maintained by government. Data obtained from Badan Pusat Statistik (2016), there were 62,47 percent of good and moderate conditions roads. The rest $(37.53 \%)$ are in damaged and seriously damaged conditions.

Moreover, the development in Indonesia is still unequally distributed. This can be indicated from duration needed from villages to their regency or district capital (figure 4).

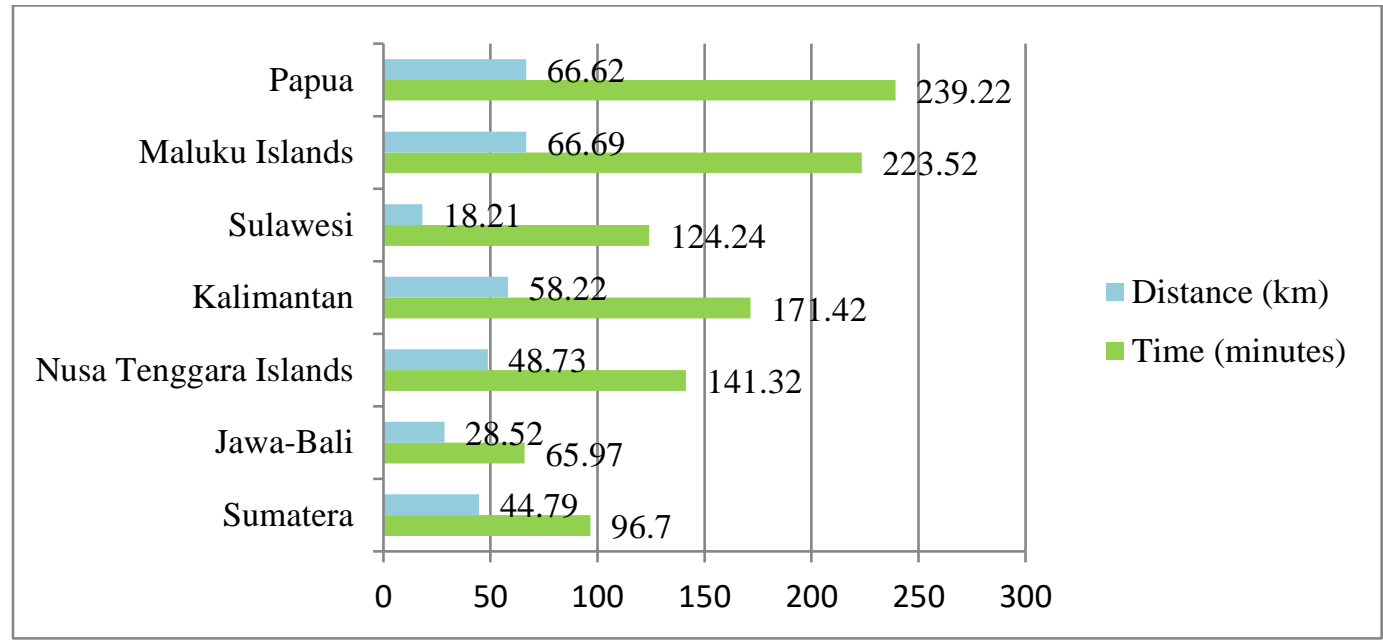

Figure 5. Access to Regency/District Capital City.

Source: Arsyad, et.al. (2011)

From figure 5, mean distance from rural areas to their regency or district capital cities in Jawa-Bali Islands are $28,52 \mathrm{~km}$ with time needed to reach is about one hour (65,97 minutes). In contrary, villages in Sulawesi are $18.21 \mathrm{~km}$ from their district capital but need far longer time to reach (124.24 minutes) comparing to those in Jawa-Bali islands. At the same time, villages in Papua, even though have similar distance with those in Maluku islands, but they need longer time to reach their district capital. That condition is caused by unequal population distribution among Indonesian population. Figure 6 shows the unequal distribution of villages in Indonesia.

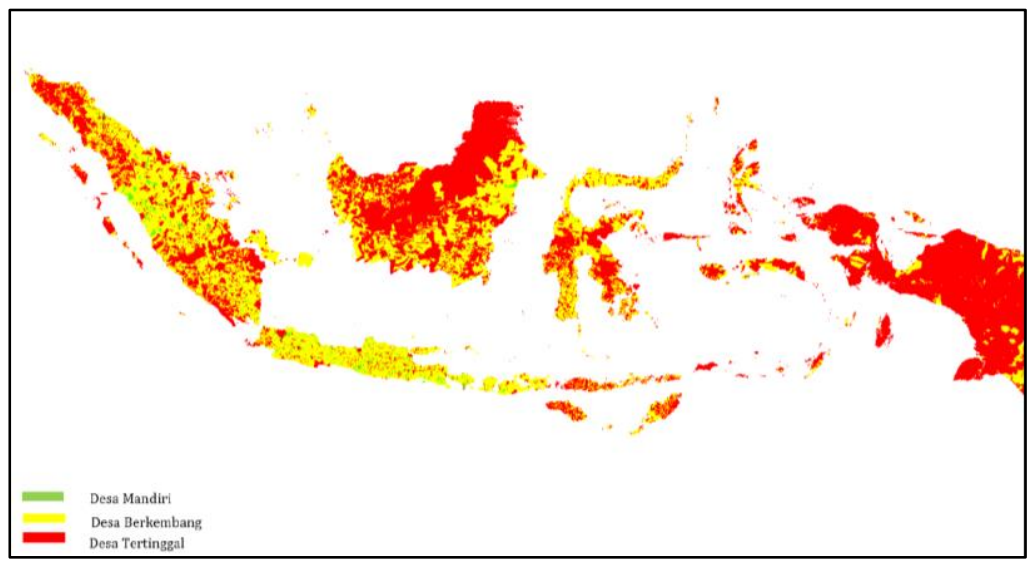

Figure 6. Villages in Indonesia based on Its Development, 2014.

Source: Kementerian PPN/ Bappenas dan Badan Pusat Statistik (2015) 


\section{PROBLEMS RELATED TO POOR ACCESSIBILITY}

The status of the unequally distributed villages has strong relationship with health condition. Provinces with adequate rural accessibility commonly have better health indicators, for instance in infant mortality rate and maternal mortality rate. Maternal mortality rate in Indonesia shows a declining trend since 1990s. The maternal mortality rate in Indonesia in 2012 was 359 per 10,000 birth, poorly increase from five years before.

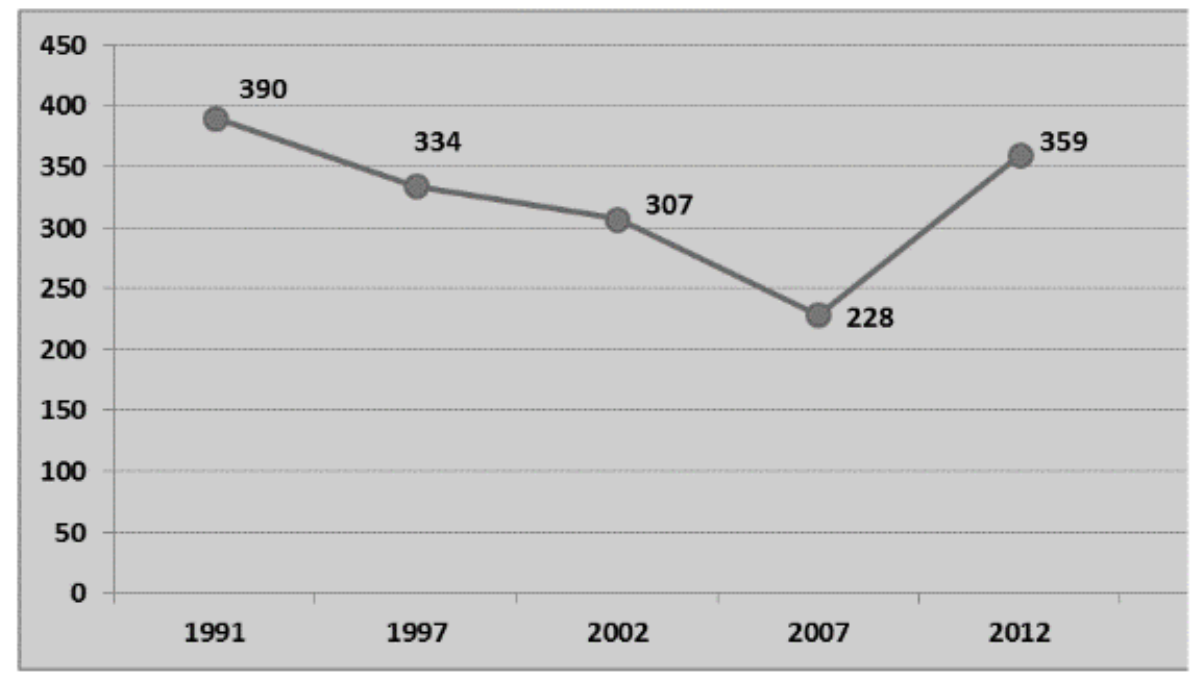

Figure 7. Maternal Mortality Rate in Indonesia,1991-2012 Source: Badan Pusat Statistik (2015)

Poor accessibility drives to unequal distribution of health practitioners. In Indonesia, most birth are overcomed by Rumah Bersalin, clinics, or caregiver clinics. There was $29,6 \%$ of mother giving birth in-house/others. It means, they probably helped by non-health practitioners. Figure 8 shows an unequal distribution among provinces in birth helped by health practitioners. In 2013. health clinics was the most frequent place for birth. The second position was house. Hospitals was in the third place.

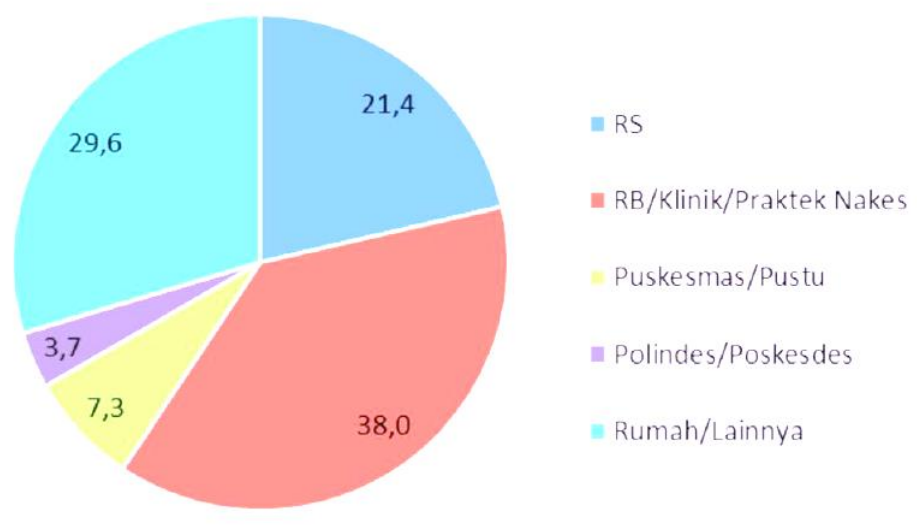

Figure 8. Proportion of Birth based on Birth Place in Indonesia, 2013 Source: BPS, SDKI 1991-2012 


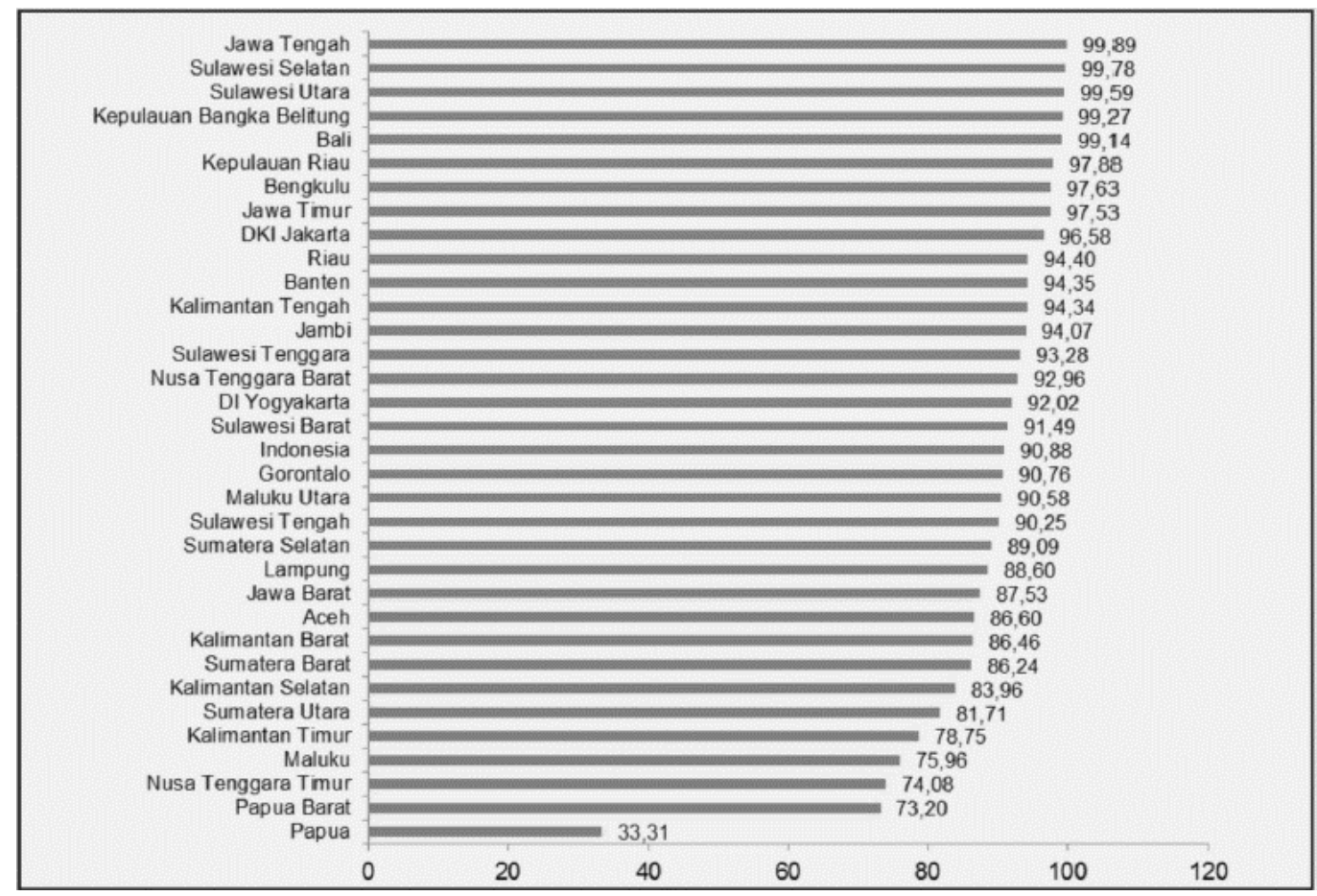

Figure 9. Birth Helped by Health Practicioners by Province, in 2013

Source: BPS, SDKI 1991-2012

In 2013, provinces with highest birth with health practitioners were Jawa Tengah, Sulawesi Selatan, and Sulawesi Utara. On the other side, Papua, Papua Barat, and Nusa Tenggara Timur had the lowest birth helped with health practitioners.

The second problem is related to infrastructure. Poor infrastructure is impeding Indonesia's growth and poverty reduction efforts. Indonesia's current GDP growth (4\%) is limited by investment, and several business climate surveys have identified "poor infrastructure" as a key bottleneck. By world comparison, Indonesia has lost competitiveness and now ranks near the bottom among its neighbors for most infrastructure indicators, as seen in table 3. The World Economic Forum's survey, the Global Competitiveness Report captures Indonesia's slide in overall infrastructure quality. In 1996 Indonesia outranked Thailand, Taiwan, China, and Srilanka. By 2002, they all surpassed Indonesia, which finished 64th out of 80 countries surveyed.

Table 3. Infrastructure Performance

\begin{tabular}{lcc}
\hline \multicolumn{1}{c}{ Indicator } & Indonesia & Regional Ranking \\
\hline Electrification Rates (\%) & 53 & 11 out of 12 \\
Fixed Telephone Lines (\%) & 4 & 12 out of 12 \\
Mobile Subscribers (\%) & 6 & 9 out of 12 \\
Access to Improved Sanitation (\%) & 55 & 7 out of 11 \\
Access to Improved Water (\%) & 78 & 7 out of 11 \\
Road Network (km per 1.000 population) & 1,7 & 8 out of 12 \\
\hline
\end{tabular}

Source: World Bank (2005) 
Giving emphasis on the transportation sector, many problems can be identified:

1. The declining spending, from $22 \%$ of the national development budget in 1993 to $11 \%$ in 2000.

2. Lack of maintenance. The proportion of road budget for maintenance reduced from $30 \%$ to below $10 \%$ from 1985 to 2000 .

3. The problem of congestion. Significant capacity expansion is needed but little has been added.

Those problems are potentially solved by enhancing accessibility, especially in rural areas. Further research needed to capture the role of accessibility to the development in quantitative analysis.

\section{CONCLUSION}

Rural accessibility can be measured by Rural Access Index (RAI). This index is provided by The World Bank. For Indonesian analysis, the RAI in 2004 index was 94 percent, indicating that 94 percent of Indonesian population are well served by adequate road condition. The rising problem is RAI cannot capture the real accessibility in Indonesia due to lack of supporting data, for example, the distribution of people. Then, the additional index are urgently needed.

The urgency to make additional accessibility measurement in Indonesia also worsened by the unequal distribution of Indonesian population. This can be seen from village concentration in several Jawa and Bali islands, leaving Papua and Maluku relatively unpopulated areas. Thus, the government must do adequate efforts to enhance accessibility and at the same time make sure that more villages can gain better access.

\section{REFERENCES}

Arsyad, L., Satriawan., E., Mulyo, J.H., \& Fitrady, A. (2011). Strategi Pembangunan Perdesaan Berbasis Lokal. Yogyakarta: UPP STIM YKPN

Ashley, C., \& Maxwell, S. (2001). Rethinking Rural Development. Development Policy Review, 19(4):395-425.

Bird, K., McKay, A., \& Shinyekwa, I. (2007). Isolation and poverty: the relationship between spatially differentiated access to goods and services and poverty. Paper presented in "Understanding and addressing spatial poverty traps: an international workshop" 29 March 2007, Spier Estate, Stellenbosch, South Africa.

Badan Pusat Statistik. (2015). Statistik Indonesia 2015 (Statistical Yearbook of Indonesia 2015).

Badan Pusat Statistik. (2016). Statistik Transportasi Darat. Jakarta: Badan Pusat Statistik. Retrieved from https://www.bps.go.id/

Fan, S., \& Kang, C. (2005). Is Small Beautiful? Farm Size, Productivity, and Poverty in Asian Agriculture. Agricultural Economics, 32(1), 135-146.

Gannon, C., \& Zhi Liu. (1997). Poverty and Transport, a World Bank Discussion Paper. Retrieved from http://siteresources.worldbank.org/.

Iimi, A., Ahmed, F., Anderson, E.C., Diehl, A.S., Maiyo, L., Peralta-Quiros, T., \& Rao, K.S. (2006). New Rural Access Index Main Determinants and Correlation to Poverty. World Bank Policy Research Working Paper 7876. Retrieved from https://openknowledge.worldbank.org/. 
Irigoyen, J.L. (2007). Rural Access and Poverty Alleviation. Powerpoint. The World Bank. Washington, DC. Retrieved from https://sustainabledevelopment.un.org/content/documents/23610411Rural Access.pdf.

Kementerian PPN/ Bappenas dan Badan Pusat Statistik. (2015). Indeks Pembangunan Desa 2014: Tantangan Pemenuhan Standar Pelayanan Minimun Desa.

Roberts, P., \& KC, S. (2005). Rural Access Index: A Key Development Indicator. Paper presented in "Seminar on Sustainable Access and Local Resource Solutions”. PIARC - RGC, Siem Reap, November 2005. Retrieved from https://www.piarc.org/.

Roberts, P., KC, S., \& Rastogi, C. (2006). Rural Access Index: A Key Development Indicator. Transport Papers TP-10. Washington: The World Bank Group.

Soseco, T. (2015). Mendorong Sektor Pendidikan di Perdesaan. Jurnal Ekonomi dan Studi Pembangunan, 7(2),1-8.

Soseco, T. (2016). Empowering Education Sector in Rural Areas. Proceedings. International Conference on Economic Education (ICEDU). 21-22 April 2016.

World Bank. (2005). Averting and Infrastructure Crisis: A Framework for Policy and Action. Retrieved from http://siteresources.worldbank.org/

World Bank. (2006). Rural Access Index: A Key Development Indicator. Retrieved from http://siteresources.worldbank.org/Overseas Development Institute, 2001.

World Bank. (2016a). Measuring Rural Access Using New Technologies. Washington, DC: World Bank.

World Bank. (2016b). Rural Access Index. Retrieved from https://data.worldbank.org/data-catalog/rural-access-index. 